\title{
Mentorship \& Counselling Program for Medical Students: Need of the Hour
}

\author{
Surabhi Sethi ${ }^{1}$, Anita Khokhar ${ }^{2}$, Jugal Kishore ${ }^{3}$, NN Mathur ${ }^{4}$
}

The medical profession is one of the most challenging professions in the world, and the five and a half year or more long curriculum of the Bachelor of Medicine and Bachelor of Surgery (M.B.B.S) degree demands not only intelligence, but also perseverance from those who pursue it. Students enter the medical profession in their late adolescence, and struggle for over half a decade, to imbibe the vast body of knowledge and acquire skills that will transform them into life-savers.

Needless to say, a majority of medical students experience difficulties in coping with the demands of the course, and frequently experience stress and various mental health issues throughout the world. In particular, the Indian studies on the magnitude of the problem also reported high prevalence of mental illness for example, $51.3 \%$ of medical students being depressed, $66.9 \%$ suffering from anxiety, $53 \%$ experiencing stress and $20.43 \%$ abusing substances. ${ }^{1-2}$

A study was carried out in medical students in Delhi where prevalence of depression and major depressive disorder using Patient health questionnaire (PHQ-9) was $21.5 \%$ and $7.6 \% .^{3}$ In another study carried out on medical students in Delhi showed that the prevalence of suicidal ideation amongst medical students was $53.6 \%$ and $4.9 \%$ students seriously contemplated suicide and $2.6 \%$ attempted suicide at least once in their life. Suicidal ideation was highest in first professional year medical students (64.4\%) and lowest among the third professional students (40.4\%).3 Authors of these studies recommended the need for a mental health program for medical students that provide for counselling services. More support need to be given to first, second and fourth year medical students in the context of study, such as providing more opportunity for recreational activities and possibly restructuring of the medical curriculum to redistribute the academic loads in different stages of training. ${ }^{4}$

Mental health issues among aspiring doctors is not only common in India, but worldwide, and in an attempt to promote academic and psychosocial wellbeing of the students, various models of Mentorship have been adopted among institutions across the globe. ${ }^{5-7}$

The 'mentor', has been explained as both a noun ("a trusted counsellor or guide") and a verb ("to serve as a mentor for"). The idea of "mentorship" for most defines a process that combines both applications of the word. 8,9 It provides a great opportunity for capacity building and investing in the future, however this requires great co-ordination and administrative support for its successful implementation. It helps develop a mentorship culture, prevents isolation and encourages the exchange of resources. Mentors help their mentees determine their dreams and goals, help them analyze their strengths and weaknesses, as well as guide them on how to improve. Steps for an effective mentor-mentee relationship include building trust, enhancing the relationship, sustaining it, and then either continuing with the student or transitioning him or her to another faculty, depending on the institutional policy.

Mentorship has found to be an effective means for helping students cope better with their academics, as well as issues such as home-sickness and challenges on the personal front. ${ }^{10}$ Studies have reported that successful implementation

${ }^{1}$ Senior Resident, ${ }^{2,3}$ Director Professor of Community Medicine, ${ }^{4}$ Principal, Vardhman Mahavir Medical College \& Safdarjung Hospital, New Delhi.

Correspondence: Dr. Jugal Kishore, Community Medicine Department, VMMC \& Safdarjung Hospital New Delhi.

E-mail Id: drjugalkishore@gmail.com

Orcid Id: http://orcid.org/0000-0001-6246-5880

How to cite this article: Sethi S, Khokhar A, Kishore J et al. Mentorship \& Counselling Program for Medical Students: Need of the Hour. Int J HealthCare Edu \& Med Inform 2017; 4(2): 1-3.

Digital Object Identifier (DOI): https://doi.org/10.24321/2455.9199.201705

ISSN: 2455-9199 
of mentorship programs yields emotional support to the students that minimises the stress of the students, as well as reservations of the parents. ${ }^{11}$

Both mentors and mentees have reported that mentees most often need guidance on time management, prioritization, and work-life balance. ${ }^{12}$ With pro-active and continuous mentoring, students report that mentorship enables them to create a view of their future professional role and integrate it with their own personalities. Their understanding of professional competence and behaviour evolve during mentorship and they make advances towards understanding the wholeness of the profession. ${ }^{13}$

Pairing of faculty members with students under the Mentorship program is not only a credible approach to support young students in their journey towards becoming doctors, but also has a multitude of benefits for the mentors. Mentoring offers various advantages to the mentors like capacity building and personality development. It helps build a socio-cultural capital and reciprocal relationships with the youth. Mentors report increased collegiality with the residents, increased personal satisfaction and an opportunity to reflect on their own practices. They feel they had made a positive impact on their mentees and that mentorship programs positively impact their lives as well. ${ }^{14}$

A mentor should display the characteristics of commitment, consistency, concern, connection, and most importantly confidentiality. Therefore, mentors need to be mentored as well, and institutions should keep holding refresher meetings for the faculty mentors to help build their skills. They need to be oriented to the objectives of the program, taught the skills of communication, and most importantly, they need to be aware of their limitations, and know what to do in case of emergencies. Conducting seminars and workshops has been shown to be an effective way to orient new mentors, as well as add to the experience of older mentors. ${ }^{15}$

A study on the perceived barriers of the mentorship program reveals the most significant challenges as mismatched expectations between mentor and mentee, lack of time or availability of mentors, and geographic separation between the mentor and mentee. On the other hand, facilitators to the program include three domains on how mentors can optimize mentorship. These include- a comprehensive focus on the mentee, setting of clear expectations, and acknowledgment of the mentors' limitations. Ways in which mentees can optimize mentorship include preparation, proactivity, continual re-evaluation of relationships, willingness to seek mentorship outside of common venues, and building of a mentorship team. ${ }^{16}$

With the multitude of benefits that the mentorship and counselling program brings with it, more and more institutions of the country are adopting and initiating them in an effort to promote well-being of their students. Program would be empowering students with the experiences of their senior teachers. Other expected outcomes of the program are - a) decease suicidal tendencies; b) increase academic performance; and c) increase satisfaction level in the college.

\section{References}

1. Iqbal S, Gupta S, Venkatarao E. Stress, anxiety \& depression among medical undergraduate students \& their socio-demographic correlates. Indian J Med Res 2015;141:354-7.

2. Arora A, Kannan S, Gowri S, Choudhary S, Sudarasanan S, Khosla PP. Substance abuse amongst the medical graduate students in a developing country. Indian J Med Res 2016;143:101-3.

3. Sidana S, Kishore J, Ghosh V, Gulati D, Jiloha RC, Anand $T$. Prevalence of depression in students of a medical college in New Delhi: A cross-sectional study. AMJ 2012, 5, 5, 247-250.

4. Goyal A, Kishore J, Anand T, Rathi A. Suicidal ideation among medical students of Delhi. Journal of Mental Health and Human Behaviour: 2012; 17(1): 60-70.

5. Sopher CJ, Adamson BJS, Andrasik MP, Flood DM, Wakefield SF, Stoff DM et al. Enhancing Diversity in the Public Health Research Workforce: The Research and Mentorship Program for Future HIV Vaccine Scientists. April 2015, Vol 105, No. 4 | Am J Public Health 2015;15(4):823-30.

6. Raub JN, Thurston TM, Fiorvento AD, Mynatt RP, Wilson SS. Implementation and outcomes of a pharmacy residency mentorship program. Am J Health Syst Pharm. 2015;72(11):S1-5. doi: 10.2146/ajhp140884.

7. Hawkins A1, Jones K, Stanton A. A mentorship programme for final-year students. Clin Teach. 2014;11(5):345-9. doi: 10.1111/tct.12149.

8. Merriam-Webster's Collegiate Dictionary. 10th ed. Springfield, Massachusetts: Merriam Webster 2001:725.

9. Tait J. What is mentorship? Can Vet J 2003;44:758-60.

10. Cohee BM, Koplin SA, Shimeall WT, Quast TM, Hartzell JD. Results of a Formal Mentorship Program for Internal Medicine Residents: Can We Facilitate Genuine Mentorship? J Grad Med Educ 2015;3:105-8. DOI: http://dx.doi.org/10.4300/JGME-D-14-00315.1.

11. Rehman R, Usmani A, Omaeer Q, Gul H. "Mentorship" a stride towards maintenance of medical student's well-being. J Pak Med Assoc. 2014;64(12):1352-7.

12. Jackevicius CA, Le J, Nazer L, Hess K, Wang J, Law AV. A Formal Mentorship Program for Faculty Development. Am J Pharm Educ 2014;78(5):101-5.

13. Kalén S, Ponzer S, Seeberger A, Kiessling A, Silén C. Longitudinal mentorship to support the development of medical students' future professional role: a qualitative study. BMC Medical Education (2015) 15:97 
DOI 10.1186/s12909-015-0383-5.

14. Champion C, Bennett S, Carver D, Tawil KE, Fabbro $\mathrm{S}$, Howatt $\mathrm{N}$ et al. Providing mentorship support to general surgery residents: a model for structured group facilitation. Can J Surg 2015;58(6):372-3. DOI: 10.1503/cjs.004315.

15. Varma JR, Prabhakaran A, Singh S, Singh P, Ganjiwale $\mathrm{J}$, Pandya $\mathrm{H}$. Experience of a faculty development workshop in mentoring at an Indian medical college. Natl Med J India 2016;29(5):286-9.

16. Leary JC, Schainker EG, Leyenaar JK. The Unwritten Rules of Mentorship: Facilitators of and Barriers to Effective Mentorship in Pediatric Hospital Medicine. Hosp Pediatr. 2016;6(4):219-25. doi:10.1542/ hpeds.2015-0108. 